\title{
Impact of KITENIN on tumor angiogenesis and lymphangiogenesis in colorectal cancer
}

\author{
HYUNG-HOON OH ${ }^{1 *}$, KANG-JIN PARK ${ }^{1 *}$, NURI KIM ${ }^{1}$, SUN-YOUNG PARK ${ }^{1}$, YOUNG-LAN PARK ${ }^{1}$, \\ CHAN-YOUNG OAK ${ }^{1}$, DAE-SEONG MYUNG ${ }^{1}$, SUNG-BUM CHO $^{1}$, WAN-SIK LEE ${ }^{1}$, \\ KYUNG-KEUN KIM ${ }^{2}$ and YOUNG-EUN JOO ${ }^{1}$ \\ Departments of ${ }^{1}$ Internal Medicine and ${ }^{2}$ Pharmacology, Chonnam National University \\ Medical School, Dong-ku, Gwangju 501-757, Republic of Korea
}

Received July 21, 2015; Accepted September 18, 2015

DOI: $10.3892 /$ or.2015.4337

\begin{abstract}
Angiogenesis and lymphangiogenesis are involved in the dissemination of tumor cells from solid tumors to regional lymph nodes and various distant sites. KAI1 COOHterminal interacting tetraspanin (KITENIN) contributes to tumor progression and poor clinical outcomes in various cancers including colorectal cancer. The aim of the present study was to evaluate whether KITENIN affects tumor angiogenesis and lymphangiogenesis in colorectal cancer. A KITENIN small interfering RNA vector was used to silence KITENIN expression in colorectal cancer cell lines including DLD1 and SW480 cells. To evaluate the ability of KITENIN to induce angiogenesis and lymphangiogenesis in human umbilical vein endothelial cells (HUVECs) and lymphatic endothelial cells (HLECs), we performed Matrigel invasion and tube formation assays. Immunohistochemistry was used to determine the expression of KITENIN in colorectal cancer tissues. Angiogenesis and lymphangiogenesis were evaluated by immunostaining with CD34 and D2-40 antibodies. KITENIN silencing inhibited both HUVEC invasion and tube formation in the DLD1 and SW480 cells. KITENIN silencing led to decreased expression of the angiogenic inducers vascular endothelial growth factor (VEGF)-A and hypoxia-inducible factor- $1 \alpha$ and increased expression of the angiogenic inhibitor angiostatin. KITENIN silencing did not inhibit either HLEC invasion or tube formation in all tested cells, but it resulted in decreased expression of the lymphangiogenic inducer VEGF-C. KITENIN expression was significantly associated with tumor stage, depth of invasion, lymph node and distant
\end{abstract}

Correspondence to: Professor Young-Eun Joo, Department of Internal Medicine, Chonnam National University Medical School, 8 Hak-Dong, Dong-ku, Gwangju 501-757, Republic of Korea

E-mail: yejoo@chonnam.ac.kr

${ }^{*}$ Contributed equally

Key words: KITENIN, angiogenesis, lymphangiogenesis, colorectal neoplasm metastases and poor survival. The mean microvessel density was significantly higher in the KITENIN-positive tumors than that in the KITENIN-negative tumors. However, the mean lymphatic vessel density of KITENIN-positive tumors was not significantly higher than that of the KITENIN-negative tumors. These results suggest that KITENIN promotes tumor progression by enhancing angiogenesis in colorectal cancer.

\section{Introduction}

Colorectal cancer is a leading cause of cancer-related death worldwide (1). Despite improved methods of early diagnosis and treatment, a large proportion of patients with colorectal cancer die from cancer progression including tumor invasion and metastasis (1-3). Cancer progression is an extremely complex process including tumor cell proliferation, invasion, apoptosis, angiogenesis, lymphangiogenesis and metastasis into distant organs or tissues (4-6). Therefore, understanding of the biological and molecular mechanisms involved in colorectal cancer progression is crucial to the development of more effective cancer therapies for preventing cancer progression.

$\mathrm{KAI} 1 / \mathrm{CD} 82$ is a member of the tetraspanin family, which is involved in cell motility, and this molecule has been identified as a suppressor of tumor spread $(7,8)$. Numerous previous studies revealed that downregulation or loss of KAI1/CD82 is associated with tumor progression and poor prognosis in many human cancers (9-13).

KAI1 COOH-terminal interacting tetraspanin (KITENIN) was recently identified as a novel KAI1/CD82-binding protein. It interacts specifically with the $\mathrm{COOH}$-terminal region of $\mathrm{KAI} / \mathrm{CD} 82$, which is crucial for the impact of KAI1/CD82 on cell motility (14-18). In contrast to KAI1/CD82, previous studies have demonstrated that KITENIN promotes the migration and invasiveness of various types of human cancer cells, and gene silencing of KITENIN via intravenous injection of short interfering RNA inhibited tumor metastasis in a mouse colon cancer model and a syngeneic mouse squamous cell tumor model (14-18). Furthermore, KITENIN expression was found to be associated with cancer progression and poor prognosis in human cancers including colorectal cancer (19-24). These data indicate that KITENIN plays an important role in cancer progression including tumor invasion and metastasis. 
Angiogenesis and lymphangiogenesis are crucial for normal growth and development in addition to protective responses such as wound healing and inflammation. However, aberrant angiogenesis and lymphangiogenesis can occur in a variety of pathological settings including tumor growth and dissemination (25-29). Many lines of evidence indicate that the progression of colorectal cancer depends on angiogenesis and lymphangiogenesis (30-33). Therefore, the role of tumor cell-derived factors in the promotion of angiogenesis and lymphangiogenesis has been extensively studied, as these factors are extremely important for understanding cancer progression. However, the potential role of KITENIN in angiogenesis and lymphangiogenesis in colorectal cancer progression has never been investigated.

The aim of the present study was to evaluate whether KITENIN affects tumor angiogenesis and lymphangiogenesis in colorectal cancer.

\section{Materials and methods}

Cell culture and siRNA transfection. DLD1 and SW480 human colorectal cancer cell lines were obtained from the American Type Culture Collection (ATCC; Manassas, VA, USA) and were maintained in Dulbecco's modified Eagle's medium (DMEM) (HyClone, Logan, UT, USA) supplemented with $10 \%$ fetal bovine serum and antibiotics. Synthesized human KITENIN small interfering RNA (siRNA) (5'-GCUUGGACUUCAGCCUCGUAGUCAA-3') and scramble siRNA (Qiagen, Germantown, MD, USA) were transfected using Lipofectamine ${ }^{\mathrm{TM}}$ RNAiMAX (Invitrogen, Carlsbad, CA, USA) according to the manufacturer's instructions. After transfection for $5 \mathrm{~h}$, the medium was replaced with serum-free DMEM, and the cells were incubated for $24 \mathrm{~h}$. Cells were re-suspended in RIPA buffer, and the supernatant was centrifuged to obtain the conditioned medium $(\mathrm{CM})$, which was used for migration and tube formation assays. Human umbilical vein endothelial cells (HUVECs; Lonza, Walkersville, MD, USA) and human lymphatic endothelial cells (HLECs; ScienCell, San Diego, CA, USA) were grown in $\mathrm{EBM}^{\mathrm{TM}}-2$ medium supplemented with $\mathrm{EGM}^{\mathrm{TM}}-2$ SingleQuots ${ }^{\mathrm{TM}}$ (Lonza).

Western blot analysis. Equal amounts of total cell lysates were separated by sodium dodecyl sulfate-polyacrylamide gel electrophoresis and transferred to PVDF membranes (BioRad, Hercules, CA, USA), which were incubated with 5\% skim milk to block non-specific binding followed by specific primary antibodies in $2 \%$ skim milk overnight at $4{ }^{\circ} \mathrm{C}$. Specific proteins were detected using horseradish peroxidase-conjugated secondary antibodies (Millipore, Billerica, MA, USA) and visualized using the LAS-4000 luminescent image analyzer (Fujifilm, Tokyo, Japan). The antibodies used in the present study were as follows: anti-human KITENIN (Atlas, Stockholm, Sweden); vascular endothelial growth factor (VEGF)-A, VEGF-C, VEGF-D and $\beta$-tubulin (Santa Cruz Biotechnology, Santa Cruz, CA, USA); and hypoxia-inducible factor-1 $\alpha$ (HIF-1 $\alpha$ ) and angiostatin (Abcam, Cambridge, UK).

Matrigel invasion assay. A Transwell filter chamber with 8- $\mu \mathrm{m}$ pores was coated with Matrigel $(1 \mathrm{mg} / \mathrm{ml}$; BD Biosciences,
San Diego, CA, USA) and was dried at room temperature. HUVECs and HLECs were plated in duplicate at a concentration of $3 \times 10^{4}$ cells/well with serum-free EGM-2 medium on the upper chamber. The lower chambers were filled with prepared $\mathrm{CM}$. After incubation for $3 \mathrm{~h}$, cells that invaded through the Transwell membrane were stained with Diff-Quik solution (Sysmex, Kobe, Japan) and were counted under a microscope.

In vitro endothelial tube formation assay. Forty-eight-well plates were coated with Matrigel $(10 \mathrm{mg} / \mathrm{ml})$ and were incubated at $37^{\circ} \mathrm{C}$ to promote polymerization. HUVECs and HLECs were re-suspended in CM and were added to each well of the plate which were coated with Matrigel. After $18 \mathrm{~h}$ of incubation, fields from each sample were photographed using an inverted microscope, and the total tube length was analyzed using the WimTube image analysis platform (Wimasis $\mathrm{GmbH}$, Munich, Germany).

Patients and tissue samples. For immunohistochemical staining, paraffin-embedded tumor samples from 85 patients who underwent surgery for colorectal cancer at the Chonnam National University Hwasun Hospital (Jeonnam, Korea) between July 2007 and June 2008, were studied. No patient had received preoperative radiotherapy or chemotherapy. Pathologic studies and clinical histories at the time of surgery were reviewed through the medical records. Tumor staging was performed in accordance with the American Joint Committee on Cancer staging system (34). Clinical outcomes were determined from the time of surgery until follow-up on December 31, 2014. The present study was approved by the Institutional Review Board of Chonnam National University Hwasun Hospital. All participants provided written consent for their information to be stored in the hospital database and used for research.

Immunohistochemistry. Paraffin-embedded tissue sections were rehydrated and retrieved with $\mathrm{pH} 6.0$ citrate buffer. Tissue sections were immersed with peroxidase-blocking solution (Dako, Carpinteria, CA, USA) to block endogenous peroxidase activity and incubated with polyclonal rabbit ant-human KITENIN, CD34 (Abcam) and D2-40 (Dako, Glostrup, Denmark) in primary diluent solution (Invitrogen) overnight at $4^{\circ} \mathrm{C}$. After washing in TBST, tissues were stained using Dako Real ${ }^{\mathrm{TM}}$ EnVision HRP/DAB detection system (Dako). The slides were counterstained with hematoxylin and were then mounted. Stained tissues were viewed and photographed using a light microscope.

Evaluation of KITENIN expression. The immunoreactive score of KITENIN expression was independently evaluated by two pathologists who were blinded to the immunostaining pattern and clinical outcomes. Consensus scores were assigned for each case by reviewing the slides with discrepancies in scoring. The staining intensity was graded on a scale of $0-3$ as follows: 0 (no staining), 1 (weak staining), 2 (moderate staining) and 3 (strong staining). The staining area was scored as 0 for no positive staining of tumor cells, 1 for positive staining in $<10 \%$ of the tumor cells, 2 for positive staining in $10-50 \%$ of the tumor cells, and 3 for positive staining in $>50 \%$ of the tumor cells. The staining index was calculated 
A

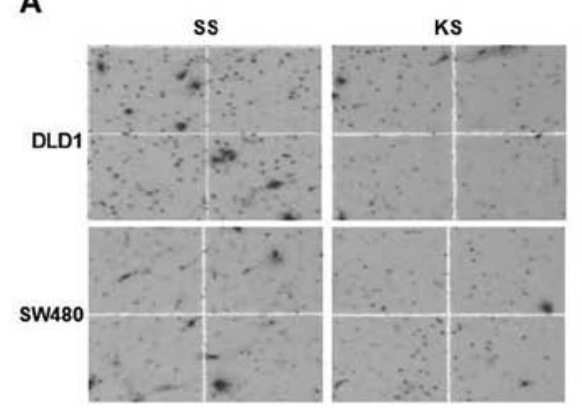

B
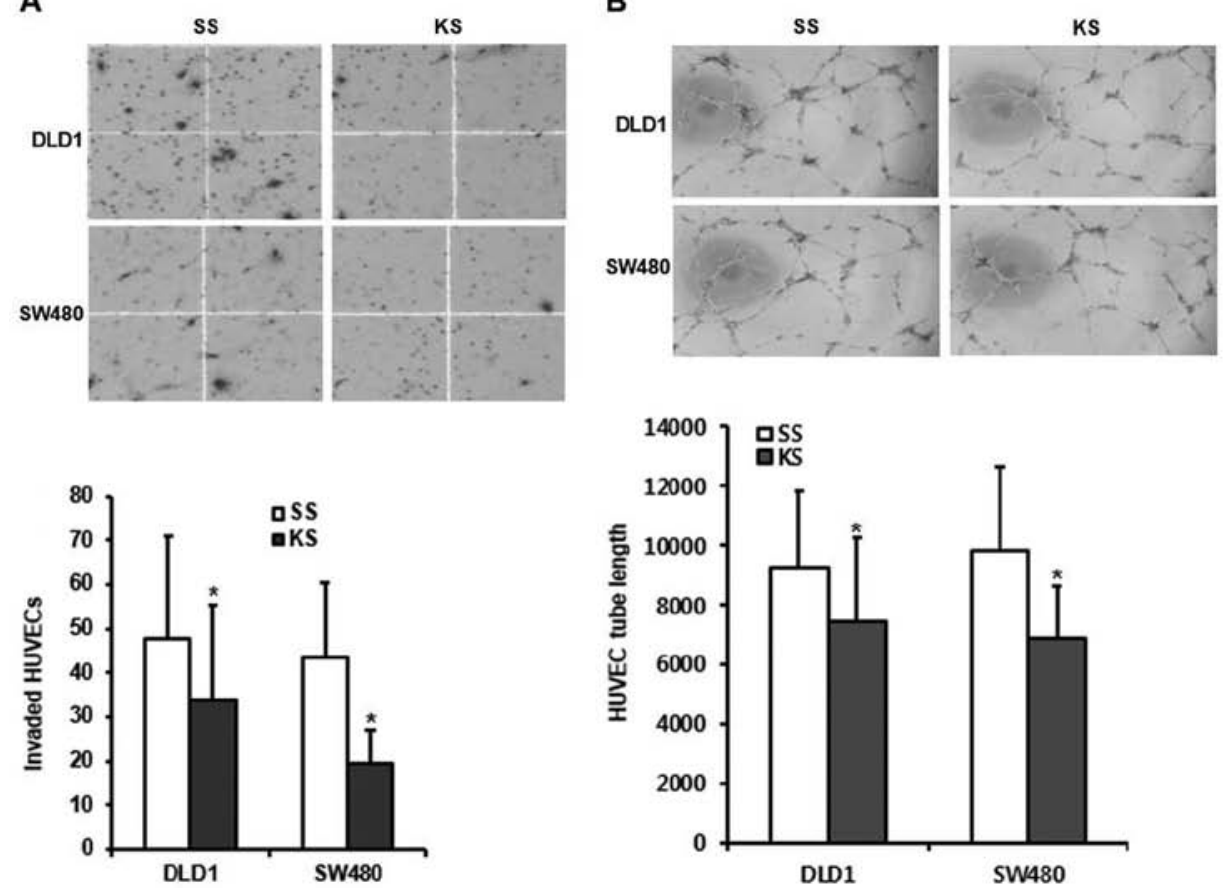

C

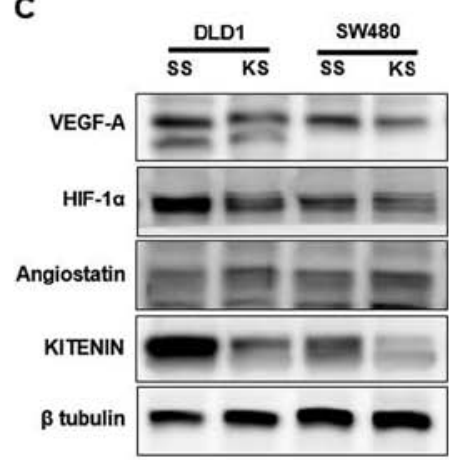

Figure 1. The impact of KITENIN silencing on angiogenesis in human colorectal cancer cells. (A) The invasiveness of HUVECs was significantly increased in the conditioned medium (CM) of KITENIN siRNA-transfected DLD1 and SW480 cells compared to the findings for the scramble siRNA-transfected cells ( $\mathrm{P}=0.031$ and 0.015 , respectively). (B) CM from KITENIN siRNA-transfected DLD1 and SW480 cells induced increased tube formation compared to that in the respective scramble siRNA-transfected cells $(\mathrm{P}=0.047$ and 0.038 , respectively). (C) KITENIN silencing resulted in decreased expression of the angiogenic inducers VEGF-A and HIF-1 $\alpha$ and increased expression of angiostatin in both tested cells. KITENIN, KAI1 COOH-terminal interacting tetraspanin; HUVEC, human umbilical vein endothelial cells; siRNA, small interfering RNA; SS, scramble siRNA; KS, KITENIN siRNA; VEGF, vascular endothelial growth factor; HIF-1 $\alpha$, hypoxia inducible factor- $1 \alpha$. ${ }^{*} \mathrm{P}<0.05$ vs. control.

as the product of the staining intensity and staining area. The tumors were determined to have positive expression (staining index $\geq 4$ ) or negative expression (staining index $<4$ ).

Assessment of microvessel density (MVD) and lymphatic vessel density (LVD). All scores and interpretations of immunohistochemical results were performed by one examiner without knowledge of the clinical outcomes. MVD and LVD were measured on anti-CD34 and anti-D2-40 antibodyimmunoreactive specimens, respectively. Vessel density was evaluated within neoplastic tissues and within healthy tissues outside the tumor. The immunostained sections were scanned at a low magnification of $x 40$ to identify the areas with the largest amount of vessels (hot spots). In the present study, three hot spots were chosen for each case with agreements of both observers, and five fields were examined in each hot spot at a high magnification of $x 200$. The average MVD and LVD were expressed as the mean value of vessels.

Statistical analysis. Statistical Package for the Social Sciences (version 15.0; SPSS, Inc., Chicago, IL, USA) was used for statistical analysis. The correlations of clinicopathological factors and recurrence with KITENIN expression, MVD and LVD were assessed using Chi-square and Fisher's exact tests. The survival rates of patients were evaluated according to the Kaplan-Meier method, and the differences were tested using a log-rank test. The subgroups of MVD and LVD were analyzed using a t-test. $\mathrm{P}<0.05$ was considered to indicate a statistically significant result.

\section{Results}

Impact of KITENIN silencing on angiogenesis in human colorectal cancer cells. To determine whether CM from KITENIN and scrambled siRNA-transfected colorectal cancer cells affects the invasiveness of HUVECs, we performed a Matrigel invasion assay. The invasiveness of HUVECs was significantly decreased in the CM of KITENIN siRNA-transfected DLD1 and SW480 cells compared to the findings for the scramble siRNA-transfected cells $(\mathrm{P}=0.031$ and 0.015 , respectively) (Fig. 1A). Next, we examined whether KITENIN silencing can stimulate endothelial tube formation, which mimics in vivo angiogenesis. CM from KITENIN siRNA-transfected DLD1 and SW480 cells less effectively stimulated tube formation than that from the respective scrambled siRNA-transfected cells $(\mathrm{P}=0.047$ and 0.038 , respectively) (Fig. 1B). KITENIN silencing led to decreased expression of the angiogenic inducers VEGF-A and HIF-1 $\alpha$ and increased expression of the angiogenic inhibitor angiostatin in both tested cells (Fig. 1C). These results suggested that KITENIN is capable of increasing both endothelial cell invasion and tube formation, key events in angiogenesis and neovascularization.

Impact of KITENIN silencing on lymphangiogenesis in human colorectal cancer cells. To evaluate the effects of KITENIN on lymphangiogenesis in HLECs, we performed Matrigel invasion and tube formation assays using CM from KITENIN and scrambled siRNA-transfected DLD1 and SW480 cells. CM 
A

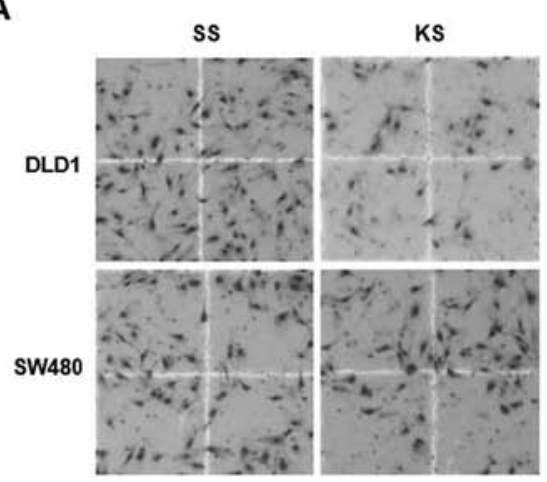

B

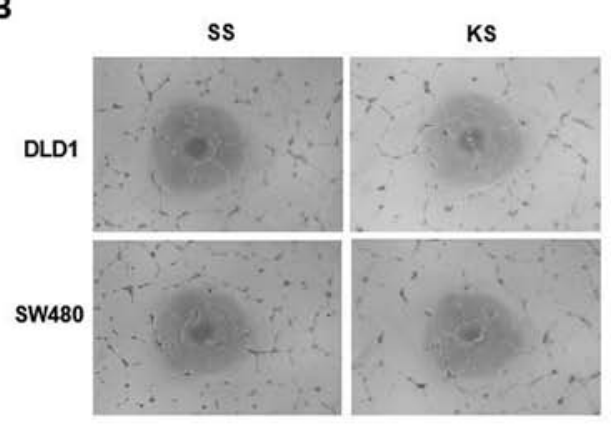

C

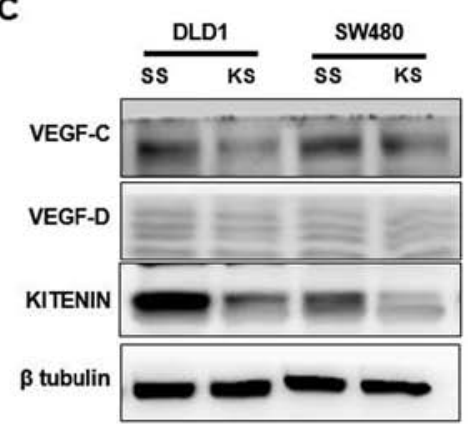

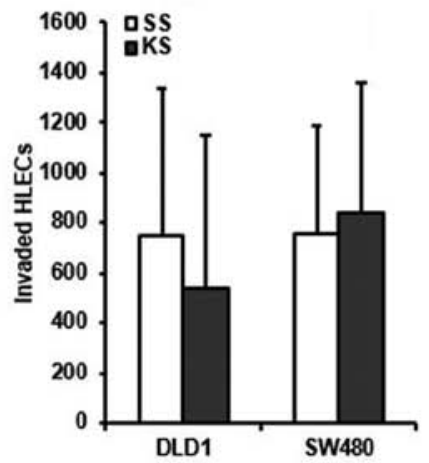

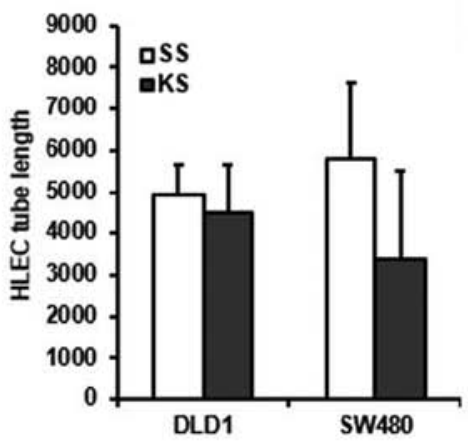

Figure 2. The impact of KITENIN silencing on lymphangiogenesis of human colorectal cancer cells. Conditioned medium (CM) from KITENIN siRNA-transfected DLD1 and SW480 cells did not inhibit invasion (A) ( $\mathrm{P}=0.080$ and 0.623 , respectively) and tube formation (B) ( $\mathrm{P}=0.235$ and 0.112 , respectively) compared to CM from the respective scramble siRNA-transfected cells. (C) KITENIN silencing resulted in decreased expression of the lymphangiogenic inducer VEGF-C, but not VEGF-D in both tested cells. KITENIN, KAI1 COOH-terminal interacting tetraspanin; HLECs, human lymphatic endothelial cells; siRNA, small interfering RNA; SS, scramble siRNA; KS, KITENIN siRNA; VEGF; vascular endothelial growth factor.

from KITENIN siRNA-transfected DLD1 and SW480 cells did not inhibit invasion $(\mathrm{P}=0.080$ and 0.623 , respectively) or tube formation $(\mathrm{P}=0.235$ and 0.112 , respectively) compared to that in the respective scrambled siRNA-transfected cells (Fig. 2A and B). KITENIN silencing resulted in decreased expression of the lymphangiogenic inducer VEGF-C, but not VEGF-D in both tested cell lines (Fig. 2C).

\section{Correlations between KITENIN and clinicopathological} features in human colorectal cancers. To study the role of KITENIN in human colorectal cancer progression, we investigated the protein expression of KITENIN immunohistochemically in formalin-fixed, paraffin-embedded tissue blocks obtained from 85 patients with colorectal cancer for whom clinicopathological data were available. Survival and the correlations between KITENIN immunostaining and clinicopathological parameters were analyzed. KITENIN immunostaining was non-existent or weak in the normal colorectal mucosa (Fig. 3A). KITENIN immunostaining was predominantly identified in the cytoplasm of cancer cells, and it was not detectable in the tumor stroma (Fig. 3B). The percentage of positive tumor cells and the staining intensity for each sample were recorded. For the 85 patient samples evaluated, positive-KITENIN expression was observed in 39 (45.9\%) colorectal cancer tissues (Table I). Immunostaining of KITENIN was significantly associated with tumor stage, depth of invasion, lymph node and distant metastasis $(\mathrm{P}<0.001$, $\mathrm{P}=0.004, \mathrm{P}<0.001$ and $\mathrm{P}=0.021$, respectively) (Table I).
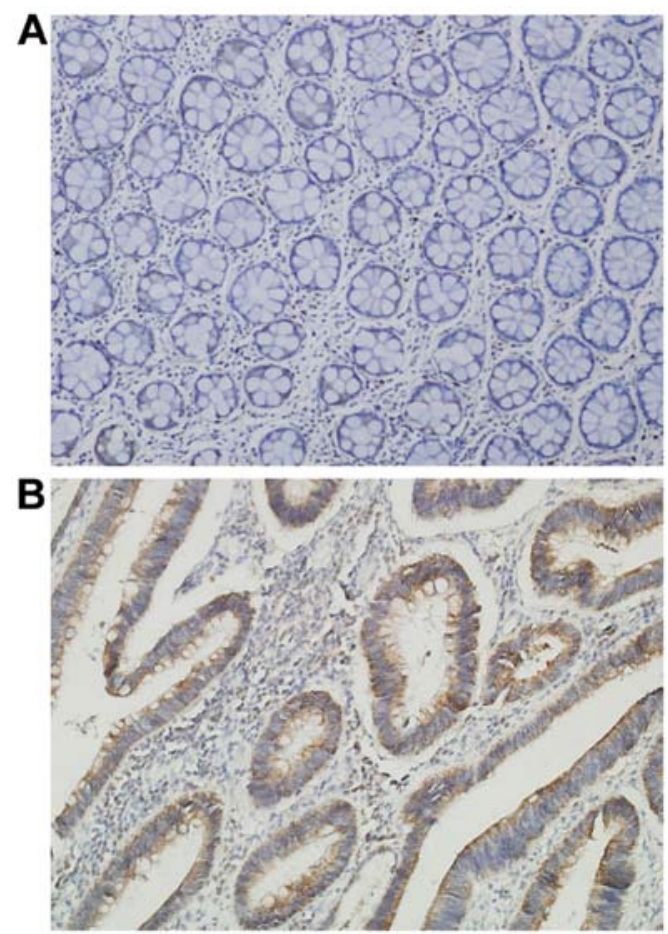

Figure 3. Expression of KITENIN protein in normal and colorectal cancer tissues by immunohistochemistry. (A) KITENIN immunostaining was negative in the normal colorectal mucosa (magnification, x200). (B) KITENIN immunostaining was predominantly identified in the cytoplasm of cancer cells, whereas it was not detectable in the tumor stroma (magnification, $\mathrm{x} 400$ ). KITENIN, KAI1 COOH-terminal interacting tetraspanin. 
Table I. Correlation between KITENIN expression and the clinicopathological parameters of the colorectal cancer cases.

\begin{tabular}{|c|c|c|c|c|}
\hline \multirow[b]{2}{*}{ Parameters } & \multirow[b]{2}{*}{$\begin{array}{l}\text { Total } \\
(\mathrm{n}=85)\end{array}$} & \multicolumn{2}{|c|}{ KITENIN } & \multirow[b]{2}{*}{ P-value } \\
\hline & & $\begin{array}{l}\text { Negative } \\
(n=46)\end{array}$ & $\begin{array}{c}\text { Positive } \\
(\mathrm{n}=39)\end{array}$ & \\
\hline Age (years) & & & & 0.073 \\
\hline$<66.1$ & 39 & 17 & 22 & \\
\hline$\geq 66.1$ & 46 & 29 & 17 & \\
\hline Gender & & & & 0.790 \\
\hline Male & 51 & 27 & 24 & \\
\hline Female & 34 & 19 & 15 & \\
\hline Tumor size $(\mathrm{cm})$ & & & & 0.778 \\
\hline$<4.9$ & 45 & 25 & 20 & \\
\hline$\geq 4.9$ & 40 & 21 & 19 & \\
\hline Histological type & & & & 0.497 \\
\hline Differentiated & 74 & 39 & 35 & \\
\hline Undifferentiated & 11 & 7 & 4 & \\
\hline Stage & & & & $<0.001$ \\
\hline $\mathrm{I} / \mathrm{II}$ & 40 & 32 & 8 & \\
\hline III/IV & 45 & 14 & 31 & \\
\hline Depth of invasion $(\mathrm{T})$ & & & & 0.004 \\
\hline $\mathrm{T} 1 / \mathrm{T} 2$ & 21 & 17 & 4 & \\
\hline $\mathrm{T} 3 / \mathrm{T} 4$ & 64 & 29 & 35 & \\
\hline $\begin{array}{l}\text { Lymph node } \\
\text { metastasis (N) }\end{array}$ & & & & $<0.001$ \\
\hline No & 43 & 33 & 10 & \\
\hline $\mathrm{N} 1-3$ & 42 & 13 & 29 & \\
\hline Distant metastasis (M) & & & & 0.021 \\
\hline M0 & 75 & 44 & 31 & \\
\hline M1 & 10 & 2 & 8 & \\
\hline
\end{tabular}

KITENIN, KAI1 COOH-terminal interacting tetraspanin.

Moreover, overall survival for patients with positive KITENIN immunostaining was significantly lower than the survival of the patients with negative immunostaining ( $\mathrm{P}=0.002)$ (Fig. 4).

Correlation between KITENIN expression and tumor cell angiogenesis or lymphangiogenesis in human colorectal cancers. All tumor samples were subjected to immunostaining for CD34 and D2-40 to identify tumor cell angiogenesis and lymphangiogenesis (Fig. 5A and B). The MVD for the 85 tumors ranged from 23.0 to 429.0 (mean, 115.2 \pm 74.7 ). The mean MVD of KITENIN-positive tumors was $133.4 \pm 85.0$, which was significantly lower than the value for KITENINnegative tumors $(\mathrm{P}=0.018)$ (Table II). The LVD for the 85 tumors ranged from 4.0 to 31.3 (mean, 13.7 \pm 5.8 ). There was no significant correlation between KITENIN expression and LVD ( $\mathrm{P}=0.528)$ (Table II).

Correlation between MVD or LVD and clinicopathological features in human colorectal cancers. The correlations between MVD or LVD and clinicopathological parameters

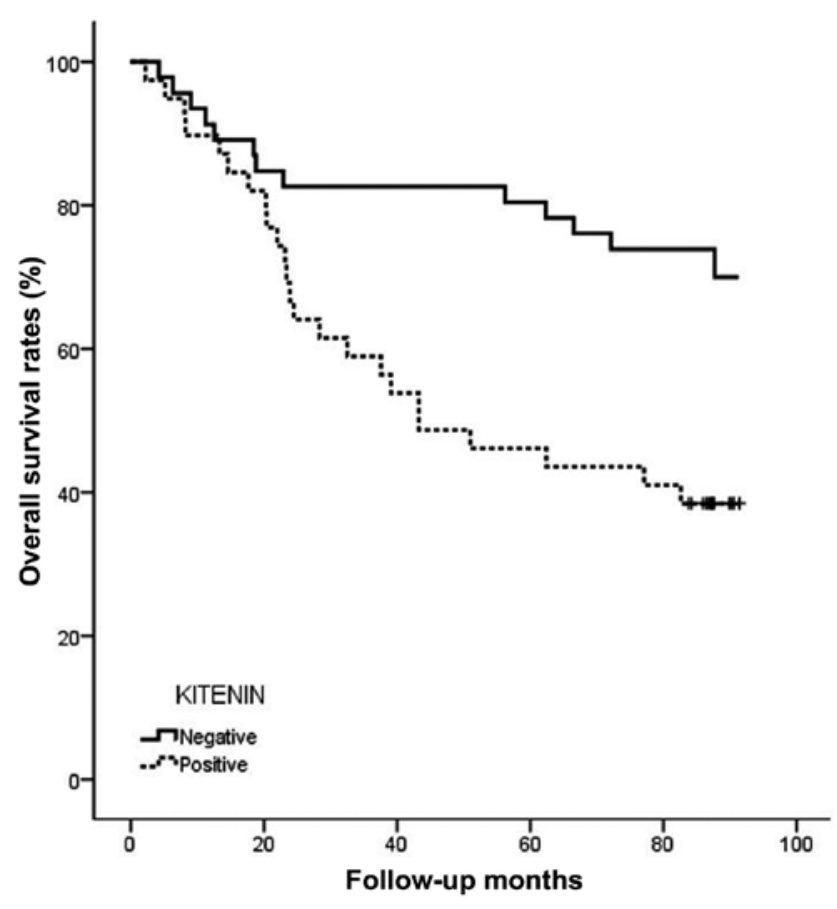

Figure 4. Kaplan-Meier survival curve correlating overall survival with positive expression (dotted line) and negative expression (solid line) of KITENIN $(\mathrm{P}=0.002)$.
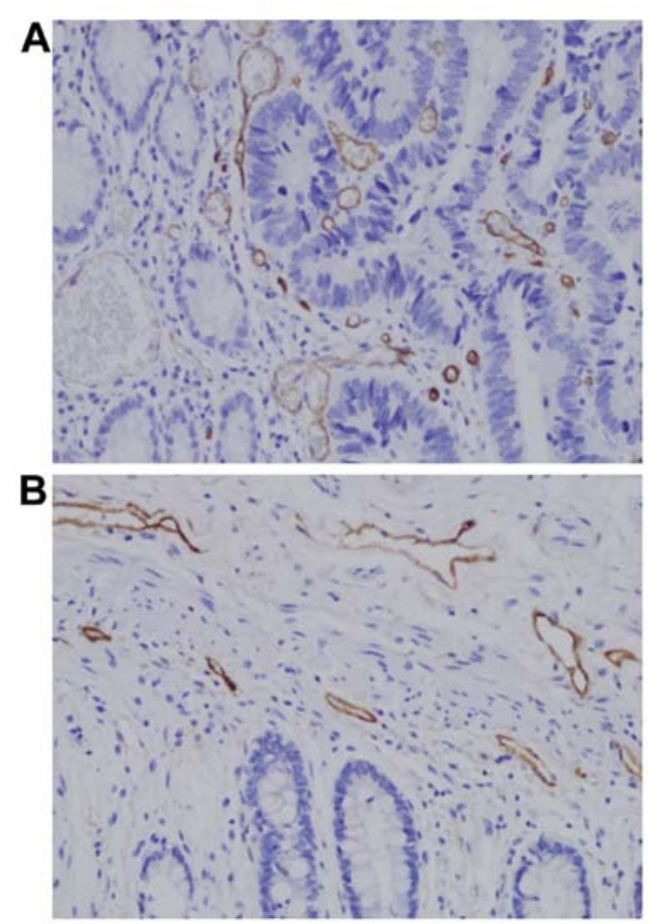

Figure 5. Assessment of tumor cell angiogenesis and lymphangiogenesis in human colorectal cancers. (A) Immunostaining of CD34. (B) Immunostaining of D2-40.

are summarized in Table III. When a mean MVD of 115.2 was chosen as the cut-off for discrimination of the 85 patients into two subgroups, 37 patients were determined to have low-MVD, whereas 48 patients had high-MVD. In addition, when a mean 
Table II. Correlation between KITENIN expression and tumor cell angiogenesis or lymphangiogenesis in the colorectal cancers.

\begin{tabular}{lcccc}
\hline & & \multicolumn{2}{c}{ KITENIN expression } & \\
\cline { 3 - 4 } Indices & $\begin{array}{c}\text { Total } \\
(\mathrm{n}=85)\end{array}$ & $\begin{array}{c}\text { Negative } \\
(\mathrm{n}=46)\end{array}$ & $\begin{array}{c}\text { Positive } \\
(\mathrm{n}=39)\end{array}$ & P-value \\
\hline $\mathrm{MVD}^{\mathrm{a}}$ & $115.2 \pm 74.7$ & $91.6 \pm 50.5$ & $133.4 \pm 85.0$ & 0.018 \\
$\mathrm{LVD}^{\mathrm{a}}$ & $13.7 \pm 5.8$ & $13.3 \pm 6.0$ & $14.0 \pm 5.7$ & 0.528 \\
\hline
\end{tabular}

KITENIN, KAI1 COOH-terminal interacting tetraspanin; SD, standard deviation; MVD, microvessel density; LVD, lymphatic vessel density. ${ }^{\mathrm{a}}$ Mean \pm SD.

Table III. Correlation between MVD or LVD and clinicopathological parameters of the colorectal cancers.

\begin{tabular}{|c|c|c|c|c|}
\hline Parameters & $\begin{array}{c}\text { MVD } \\
(\text { mean } \pm \text { SD) }\end{array}$ & P-value & $\begin{array}{c}\text { LVD } \\
(\text { mean } \pm \mathrm{SD})\end{array}$ & P-value \\
\hline Stage & & 0.387 & & 0.091 \\
\hline $\mathrm{I} / \mathrm{II}$ & $104.9 \pm 64.9$ & & $12.5 \pm 4.5$ & \\
\hline III/IV & $124.3 \pm 82.0$ & & $14.7 \pm 6.5$ & \\
\hline $\begin{array}{l}\text { Depth of } \\
\text { invasion }(\mathrm{T})\end{array}$ & & 0.179 & & 0.880 \\
\hline $\mathrm{T} 1 / \mathrm{T} 2$ & $137.4 \pm 85.4$ & & $11.7 \pm 5.0$ & \\
\hline $\mathrm{T} 3 / \mathrm{T} 4$ & $107.9 \pm 70.0$ & & $14.3 \pm 5.9$ & \\
\hline $\begin{array}{l}\text { Lymph node } \\
\text { metastasis (N) }\end{array}$ & & 0.376 & & 1.000 \\
\hline No & $107.8 \pm 67.3$ & & $13.3 \pm 5.5$ & \\
\hline N1-3 & $122.8 \pm 81.7$ & & $14.0 \pm 5.9$ & \\
\hline $\begin{array}{l}\text { Distant } \\
\text { metastasis }(\mathrm{M})\end{array}$ & & 0.795 & & 0.623 \\
\hline M0 & $112.1 \pm 69.2$ & & $13.6 \pm 6.0$ & \\
\hline M1 & $138.4 \pm 109.4$ & & $14.4 \pm 0.6$ & \\
\hline
\end{tabular}

SD, standard deviation; MVD, microvessel density; LVD, lymphatic vessel density.

LVD of 13.7 was chosen as the cut-off for discrimination of the 85 patients into two subgroups, 39 patients were determined to have low-LVD and 46 patients had high-LVD. No significant correlation was found between MVD or LVD and various clinicopathological parameters (Table III). Moreover, overall survival for patients with high-MVD or LVD was not significantly lower than that for patients with low-MVD or $\operatorname{LVD}(\mathrm{P}=0.073$ and 0.492 , respectively) (Fig. 6A and $\mathrm{B}$ ).

\section{Discussion}

Angiogenesis is an essential process needed by primary tumors to grow and invade adjacent normal structures (25-27). Angiogenesis is a complex process controlled by a balance of angiogenic and angiostatic factors involved in multiple pathways that result in endothelial cell proliferation, differentiation
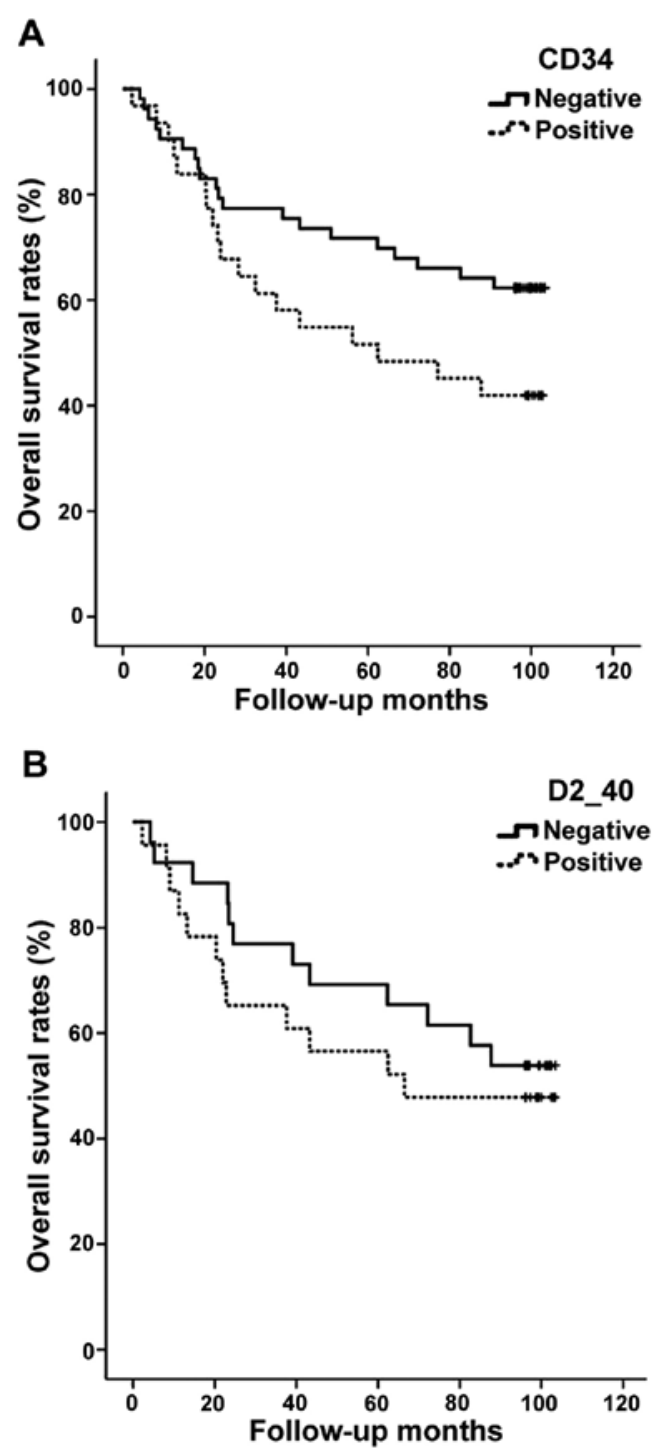

Figure 6. (A and B) Kaplan-Meier survival curve correlating overall survival with high-MVD or LVD (dotted line) and low MVD or LVD (solid line). MVD, microvessel density; LVD, lymphatic vessel density.

and organization into a functional network of vascular channels (25-27). In the present study, we investigated the role and mechanisms of KITENIN in promoting angiogenesis. In the present study, KITENIN silencing decreased both endothelial cell migration and tube formation for HUVECs, key events in angiogenesis and neovascularization. In addition, KITENIN silencing resulted in decreased expression of the angiogenic inducers VEGF-A and HIF- $1 \alpha$ and increased expression of the angiogenic inhibitor angiostatin in human colorectal cancer cells. These results indicated that KITENIN may play an important role in carcinogenesis by stimulating tumor angiogenesis in concert with angiogenic and angiostatic factors in human colorectal cancer.

Lymphangiogenesis is a dynamic process during embryogenesis that does not occur in normal adult tissue. Indeed, lymphangiogenesis is often activated in the tumor microenvironment (27-29). Malignant tumors induce lymphangiogenesis in primary tumors as well as draining sentinel lymph nodes, thereby promoting lymph 
node metastasis. The metastatic spread of tumor cells to lymph nodes is enhanced following the induction of tumor lymphangiogenesis, which is driven by lymphangiogenic factors such as VEGF-C and VEGF-D (27-29). In the present study, KITENIN silencing did not decrease either endothelial cell migration or tube formation in HLECs. In addition, KITENIN silencing resulted in decreased expression of the lymphangiogenic inducer VEGF-C, but not VEGF-D, in human colorectal cancer cells. These results suggest that although the expression VEGF-C, one of the central regulators of lymphangiogenesis, was decreased by KITENIN silencing, KITENIN may not be a major factor involved in lymphangiogenesis in colorectal cancer.

Next, we evaluated the expression of KITENIN in a well-defined series of human colorectal cancers, with special reference to patient prognosis. Previously, we reported that KITENIN expression was significantly associated with advanced stage and/or poor survival in various human cancers, including gastric, colorectal, laryngeal and oral cavity cancer, and glioma (20-24). In the present study, KITENIN expression was significantly associated with stage, depth of invasion, lymph node and distant metastasis, and poor survival. These results are in agreement with our previous studies (20-24). Therefore, KITENIN expression plays an important role in tumor progression, and this protein may serve as a potential prognostic factor and target in human colorectal cancer.

The intratumoral MVD as determined by immunohistochemistry is considered to reflect the angiogenic activity generated by neoplastic cells and the supporting stroma (35). Numerous studies have illustrated that increased angiogenesis as measured by MVD was associated with the prognosis of patients with colorectal cancer (36-38). In addition, previously, immunostaining of podoplanin (D2-40) as a molecular marker specific to the lymphatic endothelium has been used to assess lymphangiogenesis in various human cancers $(39,40)$. In the present study, when a mean MVD (or LVD) value was chosen as the cut-off for categorizing the study patients as having low or high-MVD (or LVD), although the MVD and LVD were higher for advanced tumors than for non-advanced tumors, no significant correlation was found between MVD or LVD and various clinicopathological parameters including patient survival. However, many lines of evidence indicate that MVD and LVD are associated with tumor progression and poor prognosis in colorectal cancer (36-38,41-45). These discrepancies may be attributable to the small size of in the present study population, which may have influenced some results, particularly the lack of association for various clinicopathological parameters, and to the different scoring systems and different antibodies used in immunohistochemistry as quantitative markers.

Lastly, we evaluated the correlation between KITENIN expression and tumor cell angiogenesis or lymphangiogenesis in human colorectal cancer tissues to confirm the results of our human colorectal cancer cell line studies. In the present study, the mean MVD of the KITENIN-positive tumors was significantly higher than that of KITENIN-negative tumors. However, the mean LVD of KITENIN-positive tumors was not significantly different from that of KITENIN-negative tumors. These results thus confirm the in vitro findings that KITENIN silencing inhibits angiogenesis.
Taken together, we found that KITENIN is associated with tumor progression by enhancing angiogenesis in colorectal cancer.

\section{References}

1. Brenner H, Kloor M and Pox CP: Colorectal cancer. Lancet 383: 1490-1502, 2014.

2. Park SH, Song CW, Kim YB, Kim YS, Chun HR, Lee JH, Seol WJ, Yoon HS, Lee MK, Lee JH, et al: Clinicopathological characteristics of colon cancer diagnosed at primary health care institutions. Intest Res 12: 131-138, 2014.

3. Lee CK: Clinicopathological characteristics of newly diagnosed colorectal cancers in community gastroenterology practice. Intest Res 12: 87-89, 2014.

4. Riethdorf S, Wikman H and Pantel K: Review: Biological relevance of disseminated tumor cells in cancer patients. Int $\mathrm{J}$ Cancer 123: 1991-2006, 2008.

5. Chambers AF, Groom AC and MacDonald IC: Dissemination and growth of cancer cells in metastatic sites. Nat Rev Cancer 2: 563-572, 2002.

6. Kim ER and Kim YH: Clinical application of genetics in management of colorectal cancer. Intest Res 12: 184-193, 2014.

7. Liu WM and Zhang XA: KAI1/CD82, a tumor metastasis suppressor. Cancer Lett 240: 183-194, 2006.

8. Miranti CK: Controlling cell surface dynamics and signaling: How CD82/KAI1 suppresses metastasis. Cell Signal 21: 196-211, 2009.

9. Guo XZ, Friess H, Di Mola FF, Heinicke JM, Abou-Shady M, Graber HU, Baer HU, Zimmermann A, Korc M and Büchler MW: KAI1, a new metastasis suppressor gene, is reduced in metastatic hepatocellular carcinoma. Hepatology 28: 1481-1488, 1998.

10. Dong JT, Suzuki H, Pin SS, Bova GS, Schalken JA, Isaacs WB, Barrett JC and Isaacs JT: Down-regulation of the KAI1 metastasis suppressor gene during the progression of human prostatic cancer infrequently involves gene mutation or allelic loss. Cancer Res 56: 4387-4390, 1996.

11. Adachi M, Taki T, Ieki Y, Huang CL, Higashiyama M and Miyake M: Correlation of KAI1/CD82 gene expression with good prognosis in patients with non-small cell lung cancer. Cancer Res 56: 1751-1755, 1996.

12. Schindl M, Birner P, Breitenecker G and Oberhuber G: Downregulation of KAI1 metastasis suppressor protein is associated with a dismal prognosis in epithelial ovarian cancer. Gynecol Oncol 83: 244-248, 2001.

13. Su JS, Arima K, Hasegawa M,Franco OE, Umeda Y, Yanagawa M, Sugimura Y and Kawamura J: Decreased expression of KAI1 metastasis suppressor gene is a recurrence predictor in primary pTa and pT1 urothelial bladder carcinoma. Int J Urol 11: 74-82, 2004.

14. Lee JH, Seo YW, Park SR, Kim YJ and Kim KK: Expression of a splice variant of KAI1, a tumor metastasis suppressor gene, influences tumor invasion and progression. Cancer Res 63: 7247-7255, 2003.

15. Lee JH, Park SR, Chay KO, Seo YW, Kook H, Ahn KY, Kim YJ and Kim KK: KAI1 COOH-terminal interacting tetraspanin (KITENIN), a member of the tetraspanin family, interacts with KAI1, a tumor metastasis suppressor, and enhances metastasis of cancer. Cancer Res 64: 4235-4243, 2004.

16. Lee JH, Cho ES, Kim MY, Seo YW, Kho DH, Chung IJ, Kook H, Kim NS, Ahn KY and Kim KK: Suppression of progression and metastasis of established colon tumors in mice by intravenous delivery of short interfering RNA targeting KITENIN, a metastasis-enhancing protein. Cancer Res 65: 8993-9003, 2005.

17. Kho DH, Bae JA, Lee JH, Cho HJ, Cho SH, Lee JH, Seo YW, Ahn KY, Chung IJ and Kim KK: KITENIN recruits Dishevelled/ PKC delta to form a functional complex and controls the migration and invasiveness of colorectal cancer cells. Gut 58: 509-519, 2009.

18. Lee JK, Bae JA, Sun EG, Kim HD, Yoon TM, Kim K, Lee JH Lim SC and Kim KK: KITENIN increases invasion and migration of mouse squamous cancer cells and promotes pulmonary metastasis in a mouse squamous tumor model. FEBS Lett 583: 711-717, 2009.

19. Cho SB, Park YL, Park SJ, Park SY, Lee WS, Park CH, Choi SK, Heo YH, Koh YS, Cho CK, et al: KITENIN is associated with activation of AP-1 target genes via MAPK cascades signaling in human hepatocellular carcinoma progression. Oncol Res 19: 115-123, 2011. 
20. Ryu HS, Park YL, Park SJ, Lee JH, Cho SB, Lee WS, Chung IJ, Kim KK, Lee KH, Kweon SS, et al: KITENIN is associated with tumor progression in human gastric cancer. Anticancer Res 30: 3479-3486, 2010.

21. Lee S, Song YA, Park YL, Cho SB, Lee WS, Lee JH, Chung IJ, Kim KK, Rew JS and Joo YE: Expression of KITENIN in human colorectal cancer and its relation to tumor behavior and progression. Pathol Int 61: 210-220, 2011.

22. Lee JK, Yoon TM, Seo DJ, Sun EG, Bae JA, Lim SC, Choi YD, Lee JH, Joo YE and Kim KK: KAIl COOH-terminal interacting tetraspanin (KITENIN) expression in early and advanced laryngeal cancer. Laryngoscope 120: 953-958, 2010.

23. Yoon TM, Kim SA, Lee JK, Park YL, Kim GY, Joo YE, Lee JH, Kim KK and Lim SC: Expression of KITENIN and its association with tumor progression in oral squamous cell carcinoma. Auris Nasus Larynx 40: 222-226, 2013.

24. Lee KH, Ahn EJ, Oh SJ, Kim O, Joo YE, Bae JA, Yoon S, Ryu HH, Jung S, Kim KK, et al: KITENIN promotes glioma invasiveness and progression, associated with the induction of EMT and stemness markers. Oncotarget 6: 3240-3253, 2015.

25. Mittal K, Ebos J and Rini B: Angiogenesis and the tumor microenvironment: Vascular endothelial growth factor and beyond. Semin Oncol 41: 235-251, 2014.

26. Zhao Y and Adjei AA: Targeting angiogenesis in cancer therapy: Moving beyond vascular endothelial growth gactor. Oncologist 20: 660-673, 2015.

27. Gomes FG, Nedel F, Alves AM, Nör JE and Tarquinio SB Tumor angiogenesis and lymphangiogenesis: Tumor/endothelial crosstalk and cellular/microenvironmental signaling mechanisms. Life Sci 92: 101-107, 2013.

28. Stacker SA, Williams SP, Karnezis T, Shayan R, Fox SB and Achen MG: Lymphangiogenesis and lymphatic vessel remodelling in cancer. Nat Rev Cancer 14: 159-172, 2014.

29. Duong T, Koopman P and Francois M: Tumor lymphangiogenesis as a potential therapeutic target. J Oncol 2012: 204946, 2012

30. Weng W, Feng J, Qin H and Ma Y: Molecular therapy of colorectal cancer: Progress and future directions. Int J Cancer 136: 493-502, 2015.

31. Marques I, Araújo A and de Mello RA: Anti-angiogenic therapies for metastatic colorectal cancer: Current and future perspectives. World J Gastroenterol 19: 7955-7971, 2013.

32. Royston D and Jackson DG: Mechanisms of lymphatic metastasis in human colorectal adenocarcinoma. J Pathol 217: 608-619, 2009.

33. Sun XF and Zhang H: Clinicopathological significance of stromal variables: Angiogenesis, lymphangiogenesis, inflammatory infiltration, MMP and PINCH in colorectal carcinomas. Mol Cancer 5: 43, 2006.
34. American Joint Committee on Cancer Classification (AJCC): Cancer Staging Manual. 6 edition, revised. Lippincott-Raven, Philadelphia, pp113-123, 2002.

35. Weider N, Semple JP, Welch WR and Folkman J: Tumor angiogenesis and metastasis - correlation in invasive breast carcinoma. N Engl J Med 324: 1-8, 1991.

36. Takahashi Y, Kitadai Y, Bucana CD, Cleary KR and Ellis LM: Expression of vascular endothelial growth factor and its receptor $\mathrm{KDR}$, correlates with vascularity, metastasis, and proliferation of human colon cancer. Cancer Res 55: 3964-3968, 1995.

37. Svagzdys S, Lesauskaite V, Pavalkis D, Nedzelskiene I, Pranys D and Tamelis A: Microvessel density as new prognostic marker after radiotherapy in rectal cancer. BMC Cancer 9: 95, 2009.

38. Des Guetz G, Uzzan B, Nicolas P, Cucherat M, Morere JF, Benamouzig R, Breau JL and Perret GY: Microvessel density and VEGF expression are prognostic factors in colorectal cancer. Meta-analysis of the literature. Br J Cancer 94: 1823-1832, 2006.

39. Donizy P, Rudno-Rudzinska J, Halon A, Dziegala M, Kabarowski J, Frejlich E, Dziegiel P, Kielan W and Matkowski R: Intratumoral but not peritumoral lymphatic vessel density measured by D2-40 expression predicts poor outcome in gastric cancer - ROC curve analysis to find cut-off point. Anticancer Res 34: 3113-3118, 2014.

40. Pula B, Wojnar A, Witkiewicz W, Dziegiel P and PodhorskaOkolow M: Podoplanin expression in cancer-associated fibroblasts correlates with VEGF-C expression in cancer cells of invasive ductal breast carcinoma. Neoplasma 60: 516-524, 2013.

41. Gao J, Knutsen A, Arbman G, Carstensen J, Frånlund B and Sun XF: Clinical and biological significance of angiogenesis and lymphangiogenesis in colorectal cancer. Dig Liver Dis 41: $116-122,2009$.

42. Sundov Z, Tomic S, Alfirevic S, Sundov A, Capkun V, Nincevic Z, Nincevic J, Kunac N, Kontic M, Poljak N, et al: Prognostic value of MVD, LVD and vascular invasion in lymph node-negative colon cancer. Hepatogastroenterology 60: 432-438, 2013.

43. Yan G, Zhou XY, Cai SJ, Zhang GH, Peng JJ and Du X: Lymphangiogenic and angiogenic microvessel density in human primary sporadic colorectal carcinoma. World J Gastroenterol 14: 101-107, 2008.

44. Holmqvist A, Gao J, Adell G, Carstensen J and Sun XF: The location of lymphangiogenesis is an independent prognostic factor in rectal cancers with or without preoperative radiotherapy. Ann Oncol 21: 512-517, 2010.

45. Jakob C, Aust DE, Liebscher B, Baretton GB, Datta K and Muders MH: Lymphangiogenesis in regional lymph nodes is an independent prognostic marker in rectal cancer patients after neoadjuvant treatment. PLoS One 6: e27402, 2011. 